\title{
Analisis Kinerja Keuangan Perusahaan dengan Menggunakan Du Pont System
}

\author{
Analysis of company financial performance using the du pont system
}

\section{Shifa Amalia Rahmani}

Program Studi D4 Keuangan Syariah, Politeknik Negeri Bandung

E-mail: shiaamaliar@gmail.com

\section{Hasbi Assidiki Mauluddi}

Jurusan Akuntansi, Politeknik Negeri Bandung

E-mail: hasbi.assidiki@polban.ac.id

\begin{abstract}
The development and growth of Islamic banks in Indonesia is very rapid. PT. Bank Muamalat Indonesia as a pioneer of Islamic banks in Indonesia is increasingly in the spotlight of various parties. The resulting performance is always an interesting thing to study further. The company's financial performance can be seen from the ratio of profitability, profitability, solvency and the activities it generates. One calculation tool for profitability is Return On Investment. If the Return On Investment in a company increases, then it shows the more efficient the company is in utilizing its assets, the greater the benefits that can be achieved by the company so that the company's value is also better and more efficient in generating profits. The calculation tool for calculating Return On Investment is a du pont system, where the du pont system focuses on the results of the calculation of net profit margins, total assets turn over and return on investment. The purpose of this study was to determine the financial performance of PT. Bank. Muamalat Indonesia for the period 2008-2017 with the studied variables are Net Profit Margin, Total Asset Turn Over and Return On Investment. The conclusion in this study is the net profit margin, total assets turnover and return on investment produced has a fluctuating value.
\end{abstract}

Keywords: Net Profit Margin, Total Asset Turn Over, Return On Investment, Du Pont System

\section{Pendahuluan}

Hakikat perbankan adalah lembaga yang melaksanakan tiga fungsi utama, yaitu menerima simpanan uang, meminjamkan uang, dan memberikan berbagai jasa perbankan kepada nasabah. Pada masa perekonomian kaum muslimin fungsi-fungsi ini sudah dikenal sejak zaman Rasulullah SAW. Hal tersebut juga dijelaskan dalam Pasal 1 ayat 2 Undang-Undang Nomor 21 tahun 2008 tentang perbankan syariah yaitu Bank adalah badan usaha yang menghimpun dana dari masyarakat dalam bentuk simpanan dan menyalurkannya kepada masyarakat dalam bentuk kredit dan/atau bentuk lainnya dalam rangka meningkatkan taraf hidup rakyat.

Dalam menilai kinerja suatu perusahaan maka salah satunya dapat di ambil dari gambaran profitabilitas dimana tingkat kemampuan perusahaan dalam menghasilkan suatu pendapatan maupun pemasukan yang tercermin dalam laba perusahaan, pihak manajemen selaku pelaksana dari suatu perusahaan mempunyai tanggung jawab akan berlangsungnya operasi perusahaan (Hijriyani \& Setiawan, 2017).

Kinerja keuangan perusahaan dapat dihitung dari rasio keuangan likuiditas, aktivitas, solvabilitas dan profitabilitas. Rasio profitabilitas dapat digunakan untuk memonitor 
perkembangan bank. Pihak yang berkepentingan dapat mengetahui tingkat efektivitas manajemen yang ditunjukkan melalui laba dari penjualan dan dari investasi yang telah ditanamkan pada bank (Marlina, 2015). Dari rasio-rasio tersebut, rasio yang terpenting bagi kreditor adalah rasio profitabilitas. Hal ini karena rasio profitabilitas menunjukkan kemampuan perusahaan dalam menghasilkan keuntungan. Dengan keuntungan tersebut akan menjamin pengembalian dana pinjaman dari kreditor. Berapapun besarnya likuiditas perusahaan, kalau tidak mampu menggunakan modalnya secara efisien, maka perusahaan tersebut pada akhirnya akan mengalami kesulitan keuangan, dan juga dalam pengembalian utang-utang perusahaan. Atas dasar tersebut, maka perlu adanya analisis keuangan dengan sistem $D u$ Pont sebagai pengukur profitabilitas pada perusahaan.

\section{Kajian Pustaka}

\subsection{Kinerja Keuangan}

Menurut (Rodif Hilman, Sientje Catharina Nangoy, 2014) pengertian kinerja keuangan adalah penentuan ukuran-ukuran tertentu yang dapat mengukur keberhasilan suatu organisasi atau perusahaan dalam menghasilkan laba. Kinerja perusahaan adalah hasil dari kegiatan manajemen. Parameter yang sering digunakan untuk menilai kinerja suatu perusahaan yang dilakukan dengan menggunakan pendekatan di mana informasi keuangan diambil dari laporan keuangan atau laporan keuangan lainnya. Tingkat profitabilitas digunakan sebagai dasar untuk mengukur kinerja keuangan perusahaan, hal ini dilakukan mengingat daya tarik bisnis (business attractiveness) merupakan salah satu indikator penting dalam persaingan usaha, sedangkan indikator daya tarik bisnis dapat diukur dari profitabilitas usaha, seperti ROA, ROE dan NPM (Indrawati, 2017).

\subsection{Analisis Du Pont System}

Banyaknya macam teknik analisis diatas dipergunakan untuk masing-masing fungsinya. Pada penelitian ini alat analisis yang digunakan adalah analisis dupont system. Analisis Du Pont ini digunakan untuk menilai kinerja keuangan perusahaan dengan membandingkan berbagai perkiraan dalam laporan keuangan baik neraca maupun laba rugi. tahun 1919, Du Pont Corporation mempelopori salah satu metode analisa kinerja perusahaan yang sampai dengan saat ini dikenal dengan nama Du Pont Analysis, "Analisa Du Pont System adalah analisa yang mencakup seluruh rasio aktivitas dan margin keuntungan atas penjualan untuk menunjukkan bagaimanarasio ini mempengaruhi profitabilitas" (J.Ferd Weston dan Fligene F. Bringham, 1994). Dalam tulisan ini, akan dieksplorasi berbagai rasio keuangan perusahaan yang menjadi indikator kinerja keuangan perusahaan dengan sistem Du Pont antara lain rasio aktivitas (Total Assets Turnover), rasio profitabilitas (Net Profit Margin, Return on Investment). Kenyataan bisnisnya $d u$ pont memiliki cara sendiri dalam menganalisis laporan keuangannya. Cara sebenarnya hampir sama dengan analisis laporan keuangan biasa, namun pendekatannya lebih integratif dan menggunakan komposisi laporan keuangan sebagai elemen analisisnya.

\section{Metode Penelitian}

Jenis dan sumber data jenis data yang digunakan dalam penelitian ini adalah data sekunder. Data yang berupa rasio keuangan PT. Bank Muamalat Indonesia, hasil olahan laporan keuangan PT. Bank Muamalat Indonesia periode 2008-2017 yang telah dipublikasikan. Penulis menggunakan data time series dari tahun 2008 sampai tahun 2017 yang diterbitkan oleh PT. Bank Muamalat Indonesia. Teknik analisis yang digunakan dalam penelitian ini adalah dengan menggunakan $D u$ Pont System, Dalam menganalisis data penelitian ini, penulis menggunakan metode kuantitatif, yaitu dengan melakukan perhitungan yang relevan terhadap masalah yang diteliti. 


\section{Hasil dan Pembahasan}

Penelitian ini menggunakan data historis dari laporan keuangan PT. Bank Muamalat Indonesia tahun 2008-2017 dengan menjadikan alat hitung metode Du Pont System dalam perhitungan kinerja bank tersebut dihitung melalui Net Proft Margin, Total Asset Turn Over dan Return On Investment. SelanjUtnya, dari perhitungan tersebut, penulis akan memproyeksi ROI Du Pont System untuk memperkirakan Return On Investment yang sesuai dengan standar rata-rata industri.

\subsection{Net Profit Margin}

Menentukan Rasio Margin Laba (Net Profit Margin) dengan menghitung Laba Bersih Setelah Pajak dan Pendapatan.

Perhitungan Marjin Laba $/$ Net Profit Margin $=\frac{\text { Laba Bersih }}{\text { Pendapatan }} \times 100 \%$

\section{Tabel IV.4}

Data Hasil Perhitungan Net Profit Margin PT. Bank Muamalat Indonesia Tahun 2008-2017

\begin{tabular}{|c|c|c|c|}
\hline Tahun & $\begin{array}{c}\text { Laba Bersih Setelah } \\
\text { Pajak }\end{array}$ & Pendapatan & $\begin{array}{c}\text { Net Profit } \\
\text { Margin }\end{array}$ \\
\hline 2008 & $\mathrm{Rp} 718.717 .736$ & $\mathrm{Rp} 1.468 .034 .005$ & $48.96 \%$ \\
\hline 2009 & $\mathrm{Rp} 980.639 .406$ & $\mathrm{Rp} 1.748 .296 .165$ & $56.09 \%$ \\
\hline 2010 & $\mathrm{Rp} 8.073 .716 .234$ & $\mathrm{Rp} 1,887.839,260$ & $54.66 \%$ \\
\hline 2011 & $\mathrm{Rp} 1.557 .879 .409$ & $\mathrm{Rp} 2.674 .529 .654$ & $58.25 \%$ \\
\hline 2012 & $\mathrm{Rp} 1.998 .895 .562$ & $\mathrm{Rp} 3.382 .835 .214$ & $59.09 \%$ \\
\hline 2013 & $\mathrm{Rp} 2.894 .168 .713$ & $\mathrm{Rp} 4.794 .215 .096$ & $60.37 \%$ \\
\hline 2014 & $\mathrm{Rp} 7.753 .474 .730$ & $\mathrm{Rp} 9.678 .359 .977$ & $80.11 \%$ \\
\hline 2015 & $\mathrm{Rp} 3.157 .182 .812$ & $\mathrm{Rp} 5.261 .253 .471$ & $60.01 \%$ \\
\hline 2016 & $\mathrm{Rp} 2.353 .218 .400$ & $\mathrm{Rp} 4.125 .864 .123$ & $57.04 \%$ \\
\hline 2017 & $\mathrm{Rp} 5.494 .827 .130$ & $\mathrm{Rp} 7.185 .953 .943$ & $76.47 \%$ \\
\hline Rata-Rata & & & $\mathbf{6 1 . 1 0 \%}$ \\
\hline
\end{tabular}

Sumber: Data diolah (2019)

\subsection{Total Asset Turn Over (TATO)}

Perhitungan Total Asset Turn Over $=\frac{\text { Pendapatan }}{\text { Total Aktiva }}$ 
Tabel 4.8

Data Hasil Perhitungan Total Asset Turn Over (TATO) PT. Bank Muamalat Indonesia Tahun 2008-2017

\begin{tabular}{|c|c|c|c|}
\hline Tahun & Pendapatan & Total Aktiva & TATO \\
\hline 2008 & $\mathrm{Rp} 1.468 .034 .005$ & $\mathrm{Rp} 5,525,094,802$ & 0.27 kali \\
\hline 2009 & $\mathrm{Rp} 1.748 .296 .165$ & $\mathrm{Rp} 5,418,123,044$ & $0.32 \mathrm{kali}$ \\
\hline 2010 & $\mathrm{Rp} 1,887,839,260$ & $\mathrm{Rp} 11,812,609,166$ & $0.16 \mathrm{kali}$ \\
\hline 2011 & $\mathrm{Rp} 2.674 .529 .654$ & $\mathrm{Rp} 14,030,792,086$ & $0.19 \mathrm{kali}$ \\
\hline 2012 & $\mathrm{Rp} 3.382 .835 .214$ & $\mathrm{Rp} 21,548,569,453$ & $0.16 \mathrm{kali}$ \\
\hline 2013 & $\mathrm{Rp} 4.794 .215 .096$ & $\mathrm{Rp} 25,491,972,585$ & $0.19 \mathrm{kali}$ \\
\hline 2014 & $\mathrm{Rp} 9.678 .359 .977$ & $\mathrm{Rp} 29,169,186,776$ & $0.33 \mathrm{kali}$ \\
\hline 2015 & $\mathrm{Rp} 5.261 .253 .471$ & $\mathrm{Rp} 26,642,839,794$ & $0.20 \mathrm{kali}$ \\
\hline 2016 & $\mathrm{Rp} 4.125 .864 .123$ & $\mathrm{Rp} 25,468,847,072$ & $0.16 \mathrm{kali}$ \\
\hline 2017 & $\mathrm{Rp} 7.185 .953 .943$ & $\mathrm{Rp} 27,838,626,663$ & $0.26 \mathrm{kali}$ \\
\hline Rata-Rata & & & $\mathbf{0 . 2 2}$ kali \\
\hline
\end{tabular}

Sumber: Data diolah (2019)

\subsection{Return On Investment Du Pont System}

Return On Investment $(\mathrm{ROI})=$ Net Profit Margin $(\mathrm{NPM}) \times$ Total Asset Turn Over $($ TATO $)$

\section{Tabel 4.9}

Data Hasil Rekapitulasi Perhitungan Du Pont System PT. Bank Muamalat Indonesia Tahun 2008-2017

\begin{tabular}{|c|c|c|c|}
\hline Tahun & Net Profit Margin & $\begin{array}{c}\text { Total Asset Turn } \\
\text { Over }\end{array}$ & $\begin{array}{c}\text { Return On } \\
\text { Investment }\end{array}$ \\
\hline 2008 & $48.96 \%$ & $0,27 \mathrm{kali}$ & $13,21 \%$ \\
\hline 2009 & $56.09 \%$ & $0,32 \mathrm{kali}$ & $18,10 \%$ \\
\hline 2010 & $90.41 \%$ & $0,76 \mathrm{kali}$ & $8,74 \%$ \\
\hline 2011 & $58.25 \%$ & $0,19 \mathrm{kali}$ & $11,10 \%$ \\
\hline 2012 & $59.09 \%$ & $0,16 \mathrm{kali}$ & $9,28 \%$ \\
\hline 2013 & $60.37 \%$ & $0,19 \mathrm{kali}$ & $11,35 \%$ \\
\hline 2014 & $80.11 \%$ & $0,33 \mathrm{kali}$ & $26,58 \%$ \\
\hline 2015 & $60.01 \%$ & $0,20 \mathrm{kali}$ & $11,85 \%$ \\
\hline 2016 & $57.04 \%$ & $0,16 \mathrm{kali}$ & $9,24 \%$ \\
\hline 2017 & $76.47 \%$ & $0,26 \mathrm{kali}$ & $19,74 \%$ \\
\hline Rata-Rata & $\mathbf{6 4 . 6 8} \%$ & $\mathbf{0 , 2 8} \mathbf{k a l i}$ & $\mathbf{1 3 , 6 7 \%}$ \\
\hline
\end{tabular}

Sumber: Data diolah (2019)

Berdasarkan perhitungan di atas nilai Returun On Investment yang dihasilkan oleh PT. Bank Muamalat Indonesia melalui perhitungan du pont system menunjukan nilai yang fluktuatif. Pada tahun 2008 nilai hasil perhitungan Return On Investment du pont system yakni sebesar 13,21\%. Pada tahun 2009 nilai dari hasil perhitungan Return On Investment mengalami peningkatan 4,89\% menjadi 18,10\%. Pada tahun 2010 nilai dari hasil pehitungan Return On Investment mengalami penurunan sebesar 9,36\% menjadi sebesar 8,74\%. Pada tahun 2011 nilai dari hasil perhitungan Return On Investment mengalami kenaikan 2,36\% dari tahun sebelumnya, yakni menjadi sebesar $11,10 \%$. Pada tahun 2012 nilai dari hasil perhitungan Return On Investment mengalami penurunan sebesar 1,82\% dari tahun sebelumnya, yakni menjadi sebesar 9,28\%. Pada tahun 2013 nilai dari hasil perhitungan Return On Investment mengalami kenaikan sebesar 2,07\% dari tahun sebelumnya, yakni menjadi 
11,35\%. Pada tahun 2014 nilai dari hasil perhitungan Return On Investment mengalami kenaikan yang cukup signifikan, yakni sebesar 15,23\% menjadi 26,58\%. Pada tahun 2015 nilai dari hasil perhitunngan Return On Investement mengalami penurunan yang cukup signifikan, yakni sebesar 14,73\%, menjadi sebesar 11,85\%. Pada tahun 2016 nilai dari hasil perhitungan Return On Investment mengalami penurunan sebesar 2,61\%, yakni menjadi 9,24\%. Pada tahun 2017 nilai dari hasil perhitungan Return On Investment mengalami kenaikan sebesar 10,50\%, yakni menjadi sebesar 19,74\%. Berdasarkan hasil tabel rekapitulasi data yang telah diolah, menunjukan bahwa rata-rata Return On Invetsment yang diperoleh PT. Bank Muamalat Indonesia adalah sebesar 13,67\%. Hasil itu menunjukan bahwa Return On Investment yang dimiliki oleh PT. Bank Muamalat Indonesia masih dibawah rata-rata standar industri Return On Investment yang telah ditetapkan. Return On Investment du pont adalah NPM dikalikan dengan perputaran total aktiva dimana rata - rata industrinya adalah minimal 30\% (Nuriasari, 2016). Jika Return On Investment suatu perusahaan semakin meningkat menunjukkan semakin efesien perusahaan tersebut dalam memanfaatkan aktivanya, akan semakin besar keuntungan yang dapat dicapai perusahaan sehingga nilai perusahaan tersebut juga makin baik serta efisien pula dalam menghasilkan laba. Dalam hal tersebut PT. Bank Muamalat Indonesia menunjukan kurang efektifnya tingkat pengembalian investasi yang diperoleh perusahaan. Semakin besar Return On Investment (ROI) perusahan maka semakin baik perusahan dalam memanfaatkan aktiva yang dimiliki perusahaan (Tangkere, 2014).

Nilai hasil perhitungan Net Profit Margin, Total Asset Turn Over dan Return On Investment mengalami nilai yang fluktuatif pada periode 2008-2017. Return On Investment merupakan salah satu bentuk dari rasio profitabilitas yang dimaksudkan untuk mengukur kemampuan perusahaan dengan keseluruhan dana yang ditanamkan dalam aktiva yang digunakan untuk operasinya perusahaan untuk menghasilkan keuntungan. Faktor-faktor yang mempengaruhi Return On Invesment (ROI) antara lain a). Total Asset Turnover dari operating asset (tingkat perputaran aktiva yang digunakan untuk operasi, yaitu kecepatan berputarnya aset dalam suatu periode). b) Net Profit Margin, yaitu keuntungan yang dinyatakan dalam prosentase dan jumlah penjualan bersih, profit margin ini mengukur tingkat keuntungan yang dapat dicapai oleh perusahaan dengan penjualan. Besarnya Return On Investment akan berubah kalau ada perubahan profit marginatau asset turnover baik masing-masing atau kedua-duanya. Dengan demikian maka pimpinan perusahaan dapat menggunakan salah satu atau keduanyadalam rangka usaha untuk memperbesar Return On Investment. Usaha mempertinggi Return On Investment dengan profit margin adalah bersangkutan dengan usaha untuk memertinggi efisiensi disektor operasional, pendapatan, dan administrasi. Usaha mempertinggi Return On Investment dengan memperbesar asset turnover adalah kebijaksanaan investasi dana dalam berbagai aktiva, baik aktiva lancar maupun aktiva tetap. Return On Investment selain berguna untuk keperluan kontrol, juga berguna untuk keperluan perencanaan. Misalnya Return On Investment dapat digunakan sebagai dasar untuk pengambilan keputusan kalau perusahaan atau bank akan mengadakan expansi. Dengan demikian, pengaruh Return On Investment terhadap bank syariah yaitu semakin tinggi Return On Investment yang dihasilkan maka semakin baik kinerja keuangan bank dalam menghasilkan laba begitu pula sebaliknya, sehingga bank dapat berpengaruh terhadap hubungan bank dengan nasabah atau kreditor atau dengan bank yang lain.

Adapun rata-rata hasil Total Asset Turn Over yang diperoleh PT. Bank Muamalat Indonesia adalah sebesar 0,22 kali, itu menunjukan bahwa Total Asset Turn Over yang dimiliki oleh PT. Bank Muamalat Indonesia masih dibawah rata-rata industri yang ditetapkan sebesar 2 kali setiap periode (Kasmir, 2016). TATO merupakan pengukur perputaran dari semua aset yang dimilki perusahaan. Apabila TATO suatu bank tinggi, maka menandakan kemampuan suatu bank dalam menghasilkan pendapatan dari total aktiva dikatakan baik dan merupakan pertanda bahwa manajemen dapat memanfaatkan setiap rupiah aktiva untuk mengahasilkan pendapatan. Rendah atau tingginya total asset turnover memiliki pengaruh terhadap bank syariah tersebut, 
dengan begitu apabila bank tersebut dalam mengahasilkan pendapatannya baik maka akan sangat perbengaruh terhadap citra bank itu sendiri. Tidak hanya itu, kepercayaan nasabahpun akan semakin meningkat sehingga bank tersebut akan banyak memiliki nasabah yang baru.

Hasil tabel analisis diatas rata-rata Net Profit Margin yang dihasilkan oleh PT. Bank Muamalat Indonesia sebesar 61,10\%, hal tersebut menunjukan bahwa PT. Bank Muamalat memiliki rata-rata Net Profit Margin industri yang baik. Semakin tinggi rasio NPM, maka akan menunjukkan semakin baik kinerja keuangan yang dicapai PT. Bank Muamalat Indonesia, standar industri untuk rasio NPM adalah sebesar 20\% (Kasmir, 2008). Data tabel diatas menunjukan bahwa penjualan bersifat positif terhadap laba yang didapat oleh perusahaan, yang artinya semakin besar besar penjualan atau pendapatan yang diperoleh perusahaan, maka semakin besar laba yang didapat. Hasil penelitian ini sejalan dengan uji hasil penelitian Maharani yang mengatakan bahwa penjualan berpengaruh positif pada Return On Investment. Hal ini mengindikasikan penjualan atau pendapatan perusahaan akan mempengaruhi kekuatan dari Return on Investment (ROI) (Widiarti, 2009). NPM atau margin laba memcerminkan seberapa besar laba bersih yang didapatkan bank dari pendapatan bank tersebut. Apabila NPM suatu bank tinggi, maka menandakan kemampuan suatu bank tersebut dalam memperoleh laba bersih dikatakan baik. Semakin tinggi NPM, maka kinerja bank akan semakin produktif, sehingga akan meningkatkan kepercayaan kreditor untuk menanamkan modalnya pada bank tersebut. Faktor-faktor penentu besar kecilnya profit margin pada setiap transaksi sales ditentukan oleh 2 faktor, yaitu net sales dan laba usaha. Besar kecilnya laba usaha atau net operating income tergantung kepada pendapatan dari penjualan (sales) dan besarnya biaya usaha (operating expenses). Dengan jumlah operating expenses tertentu profit margin dapat diperbesar dengan memperbesar sales, atau dengan jumalah sales tertentu profit margin dapat diperbesar dengan menekan atau memperkecil operating expenses. Dengan demikian, apabila net profit margin bank syariah tinggi akan meningkatkan tingkat kepercayaan kreditor karena para kreditor perlu mengetahui kemampuan bank dalam menghasilkan laba. Dengan mengetahui hal tersebut kreditor dapat menilai apakah bank itu profitable atau tidak. Dan pengaruhnya terhadap bank syariah yaitu apabila net profit margin rendah maka akan berdampak pada menurunnya tingkat kepercayaan nasabah terhadap bank tersebut sehingga nasabah enggan menanamkan modalnya ke bank tersebut.

Data tabel yang disajikan oleh penulis diatas, menunjukan bahwa rata-rata Return On Investment pada tahun 2008-2017 yang dihitung melalui perhitungan du pont system masih dibawah nilai standar rata-rata industri. Ini menunjukan bahwa hasil (return) atas aktiva yang digunakan kurang baik dan efektivitas manajemen dalam mengelola investasinyapun kurang baik. Secara garis besar marjin laba yang dimiliki oleh PT. Bank Muamalat Indonesia menunjukan hasil yang baik karena sudah melebihi standar rata-rata industri. Namun pada nilai rata-rata total assel turn over yang dihasilkan oleh PT. Bank Muamalat Indonesia tahun 2008-2017 masih dibawah standar rata-rata industri, hal ini menunjukan bahwa bank kurang efisen dalam pengelolaan aset yang dimilikinya.

\subsection{Proyeksi Return On Investment}

Untuk memenuhi standar Return On Investment yang dihasilkan, perusahaan bisa melakukan cara yaitu menekan biaya dan meningkatkan jumlah pendapatan yang akan menghasilkan laba bersih. Laba bersih akan mempengaruhi nilai hasil Net Profit Margin pada suatu perusahaan. Dalam penelitian ini nilai Net Profit Margin yang dihasilkan sudah sesuai dengan standar yang ditetapkan. Namun, ketika dikalikan dengan hasil perhitungan Total Asset Turn Over, perhitungan hasil Return On Investment du pont system yang dihasilkan belum sesuai dengan standar industri yang ditetapkan. Pada hasil proyeksi tersebut dapat disimpulkan jika perusahaan mendapat penambahan pada pendapatan dan laba bersih akan meningkatkan nilai net profit margin yang dihasilkan. Nilai net profit margin yang dihasilkan akan berpengaruh pada nilai hasil dari return on investment yang dihitung. 
Perusahaan perlu memperhatikan pendapatan yang diterima dan pengeluaran yang dilakukan selama kegiatan operasi berlangsung agar perusahaan dapat menghasilkan laba yang diinginkan demi keberlangsungan usahanya (Meiza Efilia, 2014). Hal tersebut didukung oleh penelitian yang dilakukan Siregar bahwa semakin besar pendapatan usaha yang didapat perusahaan maka akan semakin besar laba keuntungan yang didapat oleh perusahaan (Siregar, 2006). Selain pendapatan, biaya merupakan faktor yang sangat penting dalam setiap perusahaan, baik itu perusahaan yang bergerak dibidang jasa maupun perusahaan manufaktur, dan perhitungannya pun harus dilakukan se-efesien dan se-efektif mungkin. Seperti halnya biaya operasional yaitu biaya-biaya yang dikeluarkan oleh perusahaan untuk menjalankan aktivitas perusahaan guna mencapai tujuan dari perusahaan tersebut. Biaya operasional dapat digunakan sebagai alat untuk meningkatkan profitabilitas yang diupayakan oleh perusahaan. Biaya operasi diharapkan dapat digunakan dan mengalokasikan sumber daya yang dimiliki yang efektif dan efisien (Henry Simamora,2000).

\section{Penutup}

Berdasarkan hasil analisis data dan penelitian yang telah dilakukan, maka dapat diambil kesimpulan Pada hasil Net Profit Margin yang dihasilkan pada periode 2008-2017 memiliki rata-rata 61,10\%. Hasil tersebut menunjukan bahwa Net Profit Margin yang ditetapkan sudah lebih dari standar industri yang ditetapkan. Hal itu menunjukan bahwa bank dapat menghasilkan keuntungan atau laba bersih yang baik dalam kegiatan operasionalnya. Pada hasil Total Asset Turn Over yang dihasilkan pada periode 2008-2017 memiliki rata-rata 0,22 kali. Hasil tersebut menunjukan bahwa Total Asset Turn Over yang dihasilkan masih dibawah rata-rata industri yang ditetapkan. Hal itu menunjukan perputaran aset yang dihasilkan masih rendah dan menandakan kemampuan suatu bank dalam menghasilkan pendapatan dari total akiva kurang baik. Pada hasil Return On Investment yang dihasilkan pada periode 2008-2017 memiliki rata-rata 13,67\%. Hasil tersebut menunjukan bahwa Return On Investment yang dihasilkan masih dibawah standar rata-rata industri yang ditetapkan. Hasil Return On Investment tersebut menunjukan bahwa perusahaan tersebut kurang efisien dalam penggunaan total aktiva yang menyebabkan perusahaan kurang efisien dalam menghasilkan laba. Adapun keterbatasan penelitian ini saran bagi implikasi bagi bank syariah dengan memperbesar rata-rata Return On Investment yang dihasilkan maka diperlukan peningkatan nilai Nilai Profit Margin dan Total Asset Turn Over. Return On Investment dengan profit margin adalah bersangkutan dengan usaha untuk meningkatkan efisiensi disektor operasional, pendapatan, dan administrasi. Upaya untuk meningkatkan nilai Return On Investment dengan memperbesar total asset turn over adalah kebijaksanaan investasi dana dalam berbagai aktiva, baik aktiva lancar maupun aktiva tetap, sehingga akan meningkatkan penjualan bersih. Saran bagi masyarakat adalah mengetahui perhitungan Return On Investment bisa digunakan untuk masyarakat lebih selektif untuk memilih perusahaan yang akan dipilih untuk investasi. Masyarakat bisa melihat jeli tentang bagaimana hasil return yang akan dihasilkan oleh suatu perusahaan tersebut. Adapun saran bagi penelitian selanjuutnya adalah menambah variabel dari penelitian ini dengan variabel lain atau selain yang digunakan dalam penelitian ini sehingga dapat memperkaya literatur tentang kinerja keuangan bank tersebut.

\section{Daftar Pustaka}

Dziqron, M. (2013). Penerapan du pont system untuk mengukur kinerja keuangan perusahaan ( Studi Pada Perusahaan Semen Yang Terdaftar Di BEI Tahun 2007-2011 ) NASKAH PUBLIKASI Disusun Untuk Memenuhi Syarat Guna Memperoleh Gelar Sarjana Ekonomi Jurusan Manajemen Pada Fakultas.

Fadli, A. A. Y. (2017). Analisis Pengaruh Return on Investment ( Roi ) Dan Debt Equity Ratio ( Der) Terhadap Dividend Payout Ratio (Dpr) Pada Pt. Hanjaya Mandala Sampoerna, 17(1), 
$61-70$.

Hijriyani, N. Z., \& Setiawan, S. (2017). Analisis Profitabilitas Perbankan Syariah di Indonesia sebagai Dampak Dari Efisiensi Operasional. Jurnal Kajian Akuntansi, 1(2), 194-209.

Istanti, E. (2015). Analisis Net Profit Margin, Return On Asset dan Return On Equity dalam Mengevaluasi Kinerja Keuangan pada PT. Indospring Tbk Periode 2007-2011. E-Jurnal Manajemen BRANCHMARCK, $1(2), \quad$ 1-18. https://doi.org/10.1017/CBO9781107415324.004

Lianto, D. (2014). Penilaian Kinerja Keuangan Menggunakan Analisis Rasio, 3(11), 25-31.

Lukiana, N. (2013). Implementasi rasio keuangan untuk menilai kinerja keuangan. Jurnal WIGA, $3(2), 54-69$.

M., L. L., \& Mumu, A.K. Tungka, D. L. T. (2009). Analisis perbandingan kinerja keuangan pada pt bank sulut tbk di manado, 1-12. https://doi.org/10.2174/138920312803582960

Nur Muhammad Rizal Oktavianto, Patricia Dhiana, A. O. (2007). Pengaruh rasio likuiditas, rasio solvabilitas, dan rasio aktivitas terhadap kinerja keuangan dengan rasio profitabilitas sebagai variabel moderating (Studi Empiris pada Perusahaan Jasa Sektor Real Estate dan Property Periode 2012-2016), 23(39870423),946952.Https://doi.org/10.13989/j.cnki.05176611.2015.10.011 pada 27 Desember 2018

Lianto, D. (2014). Penilaian Kinerja Keuangan Menggunakan Analisis Rasio, 3(11), 25-31.

Lukiana, N. (2013). Implementasi rasio keuangan untuk menilai kinerja keuangan. Jurnal WIGA, $3(2), 54-69$. 